\title{
Klaus Unsicker-still going strong: congratulations on his seventieth birthday
}

\author{
W. W. Franke
}

(C) Springer-Verlag 2011

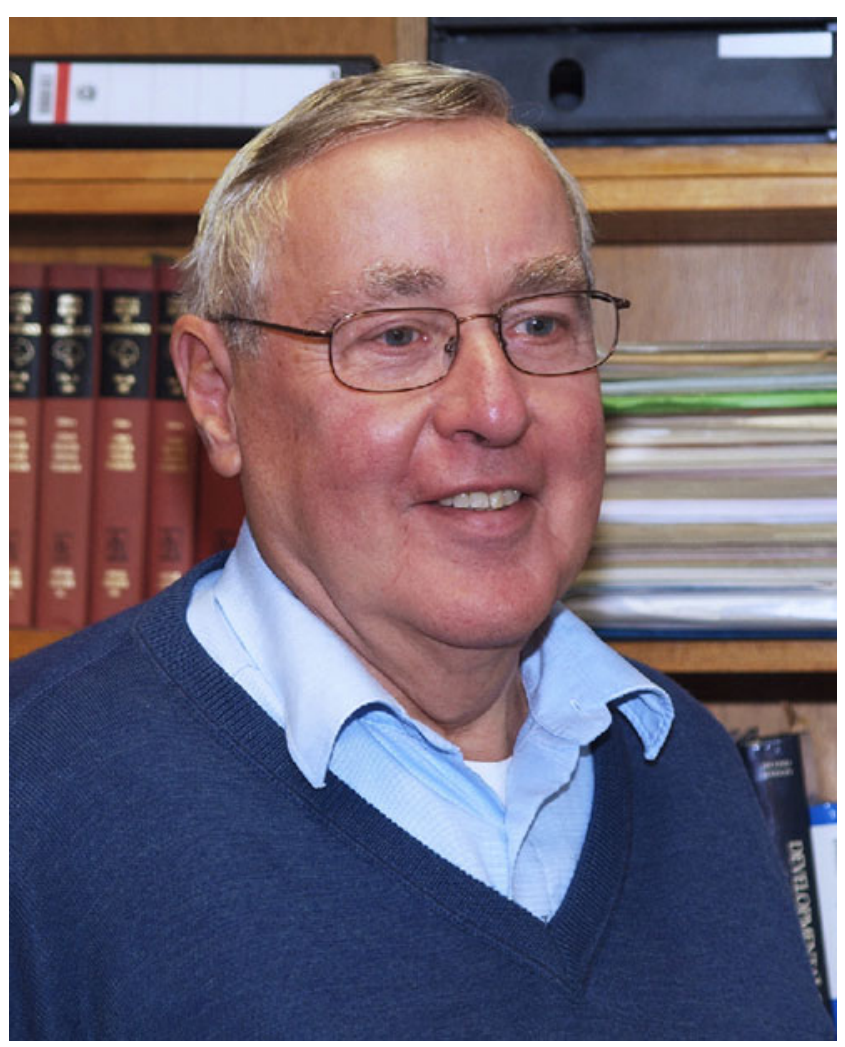

When one first meets him - as a researcher or in academic life, officially or unofficially - one might think, "Oh, my goodness, what a balanced and good-mannered Olympian

W. W. Franke $(\bowtie)$

Helmholtz Group for Cell Biology,

German Cancer Research Center,

Im Neuenheimer Feld 280,

69120 Heidelberg, Germany

e-mail: w.franke@dkfz-heidelberg.de man, standing above the trivial problems of this planet; correct, self-controlled, and always friendly. A noble textbook-scientist, from the top drawer". Only if you know him longer, more closely and more deeply, might you recognize that he is by no means, purely and simply, a holy science figure or reviewer, but that he can be quite different when necessary, courageous and outspoken. Circumstances when he notices horrendous misinterpretations of electron or immunofluorescence micrographs, for example, or little lies in legends to figures, or clever or stupid plagiarisms in manuscripts, or nepotistic conspiracies of professorial colleagues to appoint a (politically or otherwise) friend as professor are sure to drive many erythrocytes into his facial vasculature and indignation into his voice. So you can conclude with relief, "Thanks be to the creator! Klaus is still one of us: a human being". Stupidity and corrupt behavior drive him crazy, and he can even now erupt into a good old furor academicus!

Klaus Unsicker was born in Regensburg, and after his student years, graduated in 1968 with the great anatomist and histologist Wolfgang L. Bargmann in Kiel, the capital of the most northern German state of Schleswig-Holstein and, at that time, the German place of pilgrimage for histology and immunology (the pathologist in Kiel was Karl Lennert). This special academic environment has obviously infected Klaus life-long and made him into both a medical researcher and a cell biologist honoris causa. Still 34 years young, in 1976, he received a professorship at the Institute of Anatomy of Kiel University, and in 1978, he accepted the offer of a Full Professorship at and Directorship of the Institute of Anatomy and Cell Biology of the University of Marburg, followed in 1992 by an offer of the same kind by the University of Heidelberg, his final position until his Emeritus days. As proof of the high esteem in which he is held and the excellent memories that 
surround him, the University of Marburg made him Doctor honoris causa in 2003.

So, is he now finally retired? No, any compound word containing "tired" in it is wrong if used in connection with Klaus Unsicker. Since his official academic retirement in Heidelberg, he has moved southward to Freiburg University for two major reasons: first, this is the university in which his dear wife, Kerstin Krieglstein, is now Full Professor and Director of the Department of Molecular Embryology at the Institute of Anatomy and Cell Biology, and this is where the family lives. And second, here, Klaus was and is able to continue his ambitious research program on "Growth factors in development and functions of the nervous system" as part of a Special Research Program (SFB) of the German Research Foundation (DFG) at Freiburg i. Br. (SFB 592) entitled "Signaling mechanisms in embryogenesis and organogenesis". So, luckily for all sides, and notably for Klaus, the researcher, himself "The beat goes on", with both Kerstin and Klaus in the same program: Ad multos annos!

"International" is a word that immediately comes to one's mind when one looks at Klaus Unsicker's life and his attitude towards research. He was a postdoctoral fellow in Sweden, the UK, the USA, and Australia, and Visiting Professor in the USA (San Diego and the NIH in Bethesda) and in Finland (University of Helsinki). The enormously high regard in which he is held by his international colleagues is probably best demonstrated by the eminent presidencies and important offices to which he has been elected: so, inter alia, he has been President of the German Society for Anatomy and of the International Society of Developmental Neuroscience; he has been Speaker for three major SFBs and Chairman of the DFG Neuroscience Panel. He was and is a member of the editorial boards of many important journals, of which certainly the office of the Editor-inChief (Coordinating Editor) of Cell and Tissue Research is the most time-consuming. Finally, his high reputation in the field of cell biology and histology is also documented by numerous awards and elections, including the membership of the Academia Leopoldina, the Max Planck Society Research Award in 1997, the Aschoff medal in 2001, and his recent election as Honorary Member of the Romanian Society of Cell Biology.

The results of the now 326 publications of Klaus Unsicker's research, notably his findings in neuronal and neuroendocrine cells and tissues, and, in recent years in particular, his biologically and medically important contributions to our knowledge of the effects of growth factors and other trophic factors on the diverse elements of cells of the various parts of the nervous system and its development, are too voluminous and important to be discussed in such a birthday congratulation. They undoubtedly deserve a special issue of CTR all to themselves.

Werner W. Franke, Section Editor 